\title{
IMPLEMENTASI PEMBELAJARAN BACA TULIS AL-QUR'AN DENGAN METODE UMMI DI MTsN 1 JOMBANG
}

\author{
Dewi Ismatul Millah, S. Pd \\ Universitas Hasyim Asy'ari Tebuireng Jombang \\ Pos-el: dewiismatulmilla@gmail.com
}

\begin{abstract}
So far, the implementation of learning to read and weite the al-Qur'an has only been found in nonformal institutions, and for now there are already in formal institution, but only a small proportion have been able to apply various methods such as qiroati, tilawati, attartil, ummi, and so on in learning to read and write the Qur'an, one of the institutions that has implemented the method in learning to read and write the Qur'an is at Madrasah Tsanawiyah Negeri 1 Jombang which chooses the Ummi method to be applied in this learning with the aim of being able to achieve maximum results.
\end{abstract}

\begin{abstract}
ABSTRAK
Selama ini implementasi pembelajaran baca tulis al-Qur'an hanya terdapat di lembaga non-formal, dan untuk saat ini sudah ada di lembaga formal akan tetapi hanya sebagian kecil yang sudah mampu menerapkan berbagai metode seperti halnya Qiroati, Tilawati, Attartil, Ummi, dan lain sebagainya dalam pembelajaran baca tulis alQur'an, salah satu lembaga yang sudah menerapkan metode dalam pembelajaran baca tulis al-Qur'an yakni di Madrasah Tsanawiyah Negeri 1 Jombang yang mana mimilih metode ummiuntuk diterapkan dalam pembelajaran tersebut dengan tujuan mampu mencapai hasil secara maksimal.
\end{abstract}

\section{ARTICLE HISTORY}

Received 10 Agustus 2020

Revised 17 Agustus 2020

Accepted 23 Agustus 2020

\section{KEYWORDS}

Ummi Method, Learning, Read and Write al-Qur'an. 


\section{Pendahuluan}

Al-Qur'an menjadiarahan hidup untukpenganut agama Islam di Indonesia. Untuk mempelajari al-Qur'an sendiri sudah sangat penting karena dijadikannya bak asas hidup umat yang beragama Islam. Menurut Imam Hambal pada terbitanya, Cinta al-Qur'an,Para Hafidz Kecil, mengatakan bahwasannya al-Qur'an adalah kemuliaan yang paling tertinggi. Manusia yang baik adalah yang mau mempelajari dan mengajarkan atau mengamalkannya kepada yang lain, terkecuali alQur'an pun bagaikan arahan untuk keraguan semua dirasakan oleh manusia, sebagaimana perintah Allah di dalam Qs. AlBaqarah ayat 2 berbunyi:

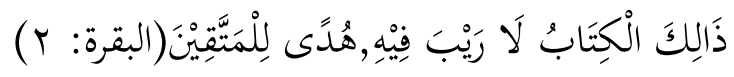

Artinya : Kitab al-Qur'an ini tidak ada keraguaannya, petunjuk bagi mereka yang bertaqwa. (Qs. al-Baqarah: 2)

Kajian ini sudah sejak masuknya Islam di Indonesia, yang berada di lingkup pesantren, dan madrasah diniyah yang sudah menjadi pusat untuk belajar al-Qur'an. Seiring berkembanya zaman kebutuhan Baca Tulis al Qur'an (BTQ) sebagian kecil telah menjadi fenomena yang sudah menyebar di manamana. karenanya berdirilah institutnon formal sebagaimana Taman Pendidikan al Qur'an (TPQ) yang sudah ada di setiap daerah serta memilih metode dari berbagai metode untuk di terapkan kajian BTQ. Hal ini juga di perkuat bersama PP. No. 55 Tahun 2007 menganai bimbingan Agama dan juga pendidikan bidang keagamaan. ${ }^{1}$

Maka dari itu diadakannya penambahan jam untuk pemahaman terkait Baca Tulis al Qur'an (BTQ) sendiri, karena merasa seperti kewajiban buat menangani persoalan dalam hal membaca dan menulis al.Qur'an (BTQ) yang semakin memprihatinkan di lingkup madrasah. Pembelajaran Baca Tulis alQur'an (BTQ) di MTsN 1 Jombang sudah ada sejak tahun 2018, yang mana

${ }^{1} Y$ uanda Kusuma, "Model-Model Perkembangan Pembelajaran BTQ di TPQ/TPA di Indonesia", Jurnal Pendidikan Agama Islam, 1, (2018), hlm. 47 
pada prosedur pengkajian Baca Tulis al-Qur'an (BTQ) hanya berpusat pada target hafalanya saja.

Setelah pembelajaran Baca Tulis al-Qur'an (BTQ) berlangsung, mengenai perkembangan atas peristiwa mengaji, mencatat, juga memahami al Qur'an masih dianggap sama, kemudian terjadinya musyawarah antara kepala madrasah, kurikulum, dan juga Ustad-Ustadzah BTQ, sampai pada akhirnya terpilihlah metode Ummi untuk di terapkan selama pembelajaran (BTQ) di MTsN 1 Jombang. Metode Ummi yang di pakai dalam pengkajianal Qur'an sebagaimana dengan metode Annahdliyah, qiroati, tilawati, tartil, juga yang lainya.

Menurut aliran behavioristik pembelajaran sendiri merupakan usaha pendidik untuk melatih perilaku peserta didi sesuau harapan sambil menyediakan area atau pancingan. ${ }^{2}$ Kebutuhan madrasah tentang wejanganal Qur'an secara baik dirasa semaki ramai. Cukup kita syukuri melainkan juga termasukkepentingan masih di imbangi dengan tersediannya Ustad-Ustadzah al Qur'an yang memegangpenguasaan serta tanggung jawab di dalam aspek pengkajian al Qur'an tersebut pantas. Karenanya Ummi Foundation ingin berkontribusi dengan semangat Faastabiqul Khairat untuk memberikansolusi terhadap masalah bagi madrasah. Dalam kajian ini mereka melewati strategi yang menjadi standarnya pengajar al qur'an atau strategi diklat bagi pengajar al qur'an dengan tujuan supaya pengkajian al Quran di masyarakat makin berkualitas.

Penerapan metode Ummi di dalam kajian Baca Tulis al.Qur'an (BTQ) sangatlah sesuai dengan kondisi lingkup MTsN 1 Jombang dan juga bagi siapa saja yang ingin menerapkannya karena metode ini mudah hendak di terapkan tatkala pemahaman Baca Tulis al-Qur'an (BTQ) dari segi membacanya, menulis, serta dapat juga ditambahkan materi-materi yang berkaitan dengan tujuan untuk mencapai kualitas siswa seperti halnya hafalan surat-surat

${ }^{2}$ Rofiatul Hosna dan Samsul, Menjelitkan Pembelajaran dengan Prinsip Prinsip Belajar (Malang: Intelegensia Media, 2015), hlm. 50 
Dewi Ismatul Millah, Implementasi Pembelajaran Baca Tulis al-Qur'an

pendek, penerapan bacaan tajwid, penerapan bacaan ghorib, dan juga yang lain sebagainya.

Proses selama pembelajaran Baca Tulis al-Qur'an (BTQ) bersama kaidah Ummi setiap harinya dimulai pada pembukaan di dalamnya terdapat salam, tanya kabar, dan juga do'a pembuka belajar al-Qur'an, setelah itu dilanjut dengan hafalan surat-surat pendek, penerapan materi menggunakan alat peraga, pemahaman materi menggunakan buku jilid, evaluasi dengan penilaian buku prestasi yang dimiliki oleh peserta didik, dan penutup, sebelum membaca do'a penutup, pengajar mengevaluasi materi yang sudah dipelajari terlebih dahulu.

\section{Metode Penelitian}

Penelitian ini mengenakan kualitatif sebagai pendekatanya, jenisnya mengenakan deskriptif kualitatif sebagaimana bermaksud hendak mendefinisikan apa saja yangsedang berlangsung saat ini atau sedang diteliti. ${ }^{3}$ Nasution sendiri menyatakan, bahwasannya dalam pendekatan kualitatif ini tidak ada pilihan lain dari pada menjadikannya manusia sebagai instrument dalam suatu penelitian. ${ }^{4}$ Data yang digunakan disini adalah anta lain terdapat data sekunder dan primer, data primer yang mana proses perencanaannya ada di lembaga atau madrasah itu sendiri, dan langsung di terima dari sumber utama, sedangkan data sekunder untuk melengkapi data primer, seperti halnya profil sekolah, visi misi sekolah, data guru, data siswa, dan yang lain sebagainya. Data awal suatu penelitian ini berupa poin dimanadata didapatkan melalui observasi, dokumentasi dan juga wawancara dengan kepala madrasah, kordinator Ummi, guru Ummi, dan juga siswa yang ikut serta dalam pembelajaran BTQ Ummi di MTsN 1 Jombang.

Untuk menentukan data yang ditentukan, teknik yang dipakai dalam pengumpulan data ini antaranya:

${ }^{3}$ M. Djumaidi Gony dan Fauzan alMansur, Metodologi Penelitian Kualitatif, (Yogyakarta: Ar-Ruuz Media, 2012), hlm. 13

${ }^{4}$ Sugiyono, Metode Penelitian Kuantitatif, Kualitatif, dan RED, (Bandung: Alfabeta, 2016), hlm. 222 
1) observasi yang dilakukan melalui pengawasan atas sasaran baik secara refleks atau tidak langsung,beserta tujuan guna mendapatkanbahan juga informasi suatu kejadian yang terjadi di madrasah tersebut,

2) wawancara yang pengumpulannya pada penyampaian pertanyaan terhadap informan dan menulis atau mengabadikanhasil interviu yang di dapatkan setelah itu di pilih mana yang berkaitan dan juga mana yang tidak berkaitan dengan persoalan yang terdapat dalam suatu penelitian,

3) pengarsipan menjadi teknik akumulasi data yang tidak spontan di tujukan dalam poin penelitian menggunakan arsip, berupa tulisan yang di dapatkan dari madrasah langsung untuk melengkapi dalam sebuah penelitian. ${ }^{5}$

Teknik kajian data yang dilakukan dalam bentuk penelitian data kualitatif, yang di peroleh melalui berbagai sumber. Proses analisis sendiri dilakukan sebelum mendatangi lapangan, selagi dilapangan, juga sehabis dilapangan, melakukan penyesuaian dan mana yang paling penting dan berkaitan untuk memperoleh gambaran yang umum dan menyeluruh terkait penggunaan metode Ummi di dalam Baca Tulis al-Qur'an (BTQ). ${ }^{6}$ Melalui cara reduction data yang mana peneliti memilah milih data yang dianggapnya perlu atau sesuai dengan apa yang dianalisis, penyampaian data di lakukan demi membangun suatu penjelasan yang di peroleh secara naratif, dan juga dengan cara penarikan kesimpulan. ${ }^{7}$

\section{Hasil dan Pembahasan}

Istilah metode bersumber pada bahasa Yunani "Methodos"mempunyai arti cara atau jalan yang di tempuh. Metode sendiri mencakup cara operasi untuk menangkap objek sebagai manadijadikan tujuan ilmu pengetahuan yang

\footnotetext{
${ }_{5}^{5}$ Mahmud, Metode Penelitian Pendidikan, (Bandung: cv Pustaka Setia, 2011), hlm. 183

${ }^{6}$ Mahmud, Metod Penelitian..., hlm. 243-245

7Sugiyono, Metode Penelitian Kualitatif......, hlm. 247-252
} 
Dewi Ismatul Millah, Implementasi Pembelajaran Baca Tulis al-Qur'an

berkaitan, fungsi metode sendiri sebaga instrumen untuk mendekati suatu misi. ${ }^{8}$

Ummi bermula dari bahasa Arab "Ummun" mempunyai arti Ibuku. Pemilihan kata ini bermaksud tujuan untuk menyanjung juga mengenang jasa seorang Ibu, karena Ibulah yang mengenalkan banyak hal terhadap anaknya, dan metode Ummi sendiri menjadi salah satu metode ini di terapkan pada pengkajian Baca Tulis al-Qur'an (BTQ) di MTsN 1 Jombang. Metode Ummi di sini di terapkan untuk anak-anak MTs, yang mana metode ini lebih dianalogikan kepada bahasa Ibu, yang mana menirukan perkataan seorang Ibu, misalnya kalimat "SAJADA", bahwa selama belajar membaca tatkala pengejaannya langsung per suku kata (sa-ja-da), di sini anak-anak tidak dikenalkan dengan secara langsung per huruf $(s-a-j-a-d-a)$, metode Ummi mampu mengantarkan suatu proses belajar al-Qur'an sehingga dapat menghasilkan produk yang cepat. Pendekatan yang di terapkan pada pengkajian Baca Tulis al-Qur'an (BTQ) ini melalui beberapa pendekatan, di antaranya:

a. Direct Metodhe (Metode Langsung), dalam pendekatannya secara langsung, tidak banyak definisi.

b. Repeatition (Di ulang-ulang), Dalam menghafal maka dilakukannya dengan cara berulang-ulang agar peserta didik mampu mencapai kekuatan dalam hafalan, keindahan dalam bacaan, dan kemudahan dalam mengingat hafalan.

c. Kasih Sayang yang Tulus. Pengaruh cinta, kasih sayang, juga ketenangan hati seorang Ibu merupakan kunci dari kesuksesan. ${ }^{9}$

Al Qur'an sendiri menjadi suatu keharusan untuk di pelajari seluruh umat beragama Islam di kalangan dunia, sebagaimana pemakaian metode ummi terhadap pembelajaran Baca Tulis al-Qur'an (BTQ) di MTsN 1 Jombang

\footnotetext{
${ }^{8}$ Agus KurniaImplementasi Metode Al-Hidayah dalam Pembelajaran Baca Tulis al-qur'an, Jurnal Tatsqif, Jurnal Pemikiran dan Penelitian Pendidikan, Vol. 15, No. 1, 2017

9Ummi Foundation, Modul sertifikasi Metode Ummi, (Surabaya: Ummi Foundation, 2012), hlm. 45
} 
menjadikan lebih unggul sehingga dirasa sangat berpengaruh terhadap peningkatan terhadap diri siswa MTsN 1 Jombang dalam keterampilan terhadap bacaan al Qur'an, menulis al.Qur'an, dan juga mampu mengimplementasikan dalam pemahaman yang terkandung di dalam al Qur'an. Sebagaimana dasar-dasar al.Qur'an yang ada di Qs. Al Alaq ayat 1-5:

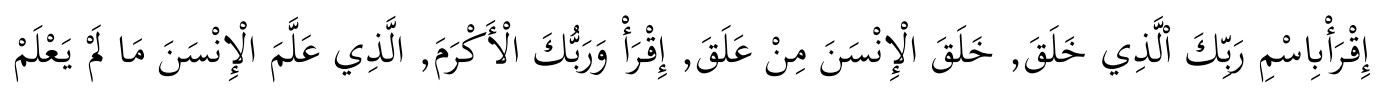

Yang mempunyai arti : Bacalah dengan (menyebut) nama TuhanMu yang menciptakan, dia telah menciptakan manusia dari segumpal darah, bacalah, dan TuhanMulah yang Maha Mulia, yang mengajar (manusia) melalui pena, dan mengajarkan manusia apapun yang tidak diketahuinya. ${ }^{10}$

Baca tulis al Qur'an (BTQ) sendiri dikatakan sebagai prosedur studi berkaitan dengan mempelajari dengan cara membaca juga menulis al Qur'an secara baik dan benar sesuai dengan kaidahnya, akan tetapi juga usaha sadar untuk memberikan pemahaman terhadap siswa dalam mengenal dengan secara rinci bagaimana cara membaca dan menulis permulaan huruf-huruf hijaiyyah sehingga menjadikan siswa lebih mudah memahaminya. Tujuan dari pembelajaran ini sendiri yaitu:

1. Belajar membaca, memahami, dan menyempurnakan bacaan dengan baik dan benar

2. Memberikan pemahaman mengenai cara membaca, menulis secara baik dan benar

3. Memberikan pemahaman terkait apa saja yang ada di dalam isi kandungan alQur'an

4. Memberikan pemahaman terkait dengan akidah Islam

5. Menjadikan siswa lebih senang membaca alQur'an

6. Memahami bahwa al.Qur'an merupakan kitab suci yang sudah terbukti kebenarannya

${ }^{10}$ Qs. Al-Alaq (96): 1-5 
7. Memberi pemahaman kepada siswa terkait konsep dalam membaca juga menulis alQur'an

Selain terdapat tujuan pada suatu kajian Baca Tulis al-Qur'an (BTQ) terdapat pula manfaat yang terkait pembelajaran tersebut di MTsN 1 Jombang, antara lain:

1. BTQ sebagai alat pengantar, yaitu mengantarkan siswa untuk sanggup mempelajari al-Qur'an secara baik dan benar.

2. BTQ sebagai pengajaran, yaitu guru menyampaikan ilmu terkait membaca juga menulis alQur'an sehingga sisiwa mampu terampil dan menguasai semua huruf al-Qur'an.

3. Sebagai pedoman hidup yaitu Setiap ayat terdapat di dalam al.Qur'an mengandung 10 manfaat mampu dijadikan pedoman hidup manusia menuju kebaikan, kebenaran, dan keselamatan dunia akhirat.

4. Sebagai penenang hati, yaitu Penenang bagi siapapun yang mau membacan, seorang giat membaca al-Qur'an maka akan mempunyaihati yang amat tenang, kesabaran, bersihnya hati, pribadi dan fikiran yang positif juga memiliki cahaya penuh di wajahnya.

5. Menjadi pelindung diri, yaitu Siapapun yang istiqomah membaca al-Qur'an maka akan merasa setiap gerakannya selalu dijaga oleh Allah.

6. Sebagai motivasi, yaitu Bukan hanya bagi siapa saja yang mau membacanya, akan tetapi juga bagi siapa saja yang memahami dan mau mengamalkannya maka akan terdapat hikmah, manfaat, dan kenikmatan al.Qur'an

7. Sebagai peringatan dan teguran yaitu AlQur'an bisa sebagai pelebur rasa emosi yang mampu memberikan ketenangan, selain itu juga al-Qur'an mampu menghindarkan dari rasa kecemasan, kekhawatiran, kesedihan, selalu merasa gembira. 
8. Sebagai alat komunikasi dengan Allah yaitu, AlQur'an juga merupakan alat penghubung hamba dengan sang pencipta, dan juga dijadikan sarana untuk lebih mendekatkan diri kepada pencipta.

Cara memahami alQur'an dengan baik dan jugaakurat menjadikanmasalah besar oleh umat ber-agama Islam. lantaran kesalahan dalam membacakan alQur'an maka mampu merubah arti yang terkandung dalam al-Qur'an tersebut, maka pebelajaran BTQ ini salah satunya sebagai cara untuk membenarkan kembali prosedur membaca al.Qur'an. Selain itu juga terdapat alasana pentingnya dalam pembelajaran BTQ ini, antara lain sebagai berikut:

1. Sebagai hal yang wajib dalam pemahaman alQur'an Pemahaman dalam cara menulis dan membaca al.Qur'an, mampu faham akan huruf-huruf hijaiyyah, memahami hukum-hukum tajwidnya, mampu menerapkan bacaan ghoribnya, yang harus dikuasai agar tidak terjadi salah dalam penafsirannya.

2. Menjaga kemurnian al-Qur'an berasal perubahan lafad jugaartinya Untuk mengontrol kemurnian alQur'an, adanya globalisasi membuahkan keberadaan al-Qur'an tersisihkan di karenakan terdapat peningkatan teknologi yang sekarang lebih cepat dan maju. Sebagaimana problematika manipulasi ayat alQur'an sertaelaborasi makna yang amat bertentangan. Sehingga sangat dianggap perlunya BTQ ini utnuk diterapkan di madrasah.

3. Sebagai motivasi siswa

Motivasi untuk siswa agar lebih istiqomah dalam mempelajari alQur'an, memahami isi yang terdapat dalam alQur'an, dan mampu mempraktikkan, selain itu juga sebagai tiang dan petunjuk kehidupan sehari-harinya.

4. Awal modal siswa 
Dengan bekal utama dalam kemampuan Baca Tulis alQur'an (BTQ) maka siswa tidak akan merasa kesulitan dalam mempelajari ilmu lain, seperti mata pelajaran Bahasa Arab, dan lain sebagainya.

5. Meningkatankan pengetahuan terhadap siswa dalam segi psikologis, ketaksaan, maupun psikomotorik

Psikologis merupakan kemampuan intelektual siswa dalam berfikir, memahami, serta menyelesaikan masalah. Afektif maupun intelektual terlebih mengenai sikap, minat, emosi, dan nilai hidup. Psikomotorik ialahketerampilan yang berkaitan dengan jasmani, terlebih mengorientasikan terhadap proses perilaku atau aktualisasi. ${ }^{11}$

BTQ sendiri dianggap mencakup tiga aspek tersebut karena selain mempelajari pemahaman terkait umum juga mempelajari ilmu agama melalui al-Qur'an. Dalam pelaksanaannya sendiri mengenai masalah mengkaji dan mencatat alQur'an, pelajar diberi pemahaman sedikit terkait pengetahuan yang terdapat di dalam al.Qur'an, mengamalkan perintah Allah dan menjauhi larangan Allah.

1. Sebagai mukjizat. Karena pada dasarnya alQuran sebagai mukjizat yang amat paling utama di turunkan pada malaikan jibril dan di wahyukan kepada Nabi Muhammad Saw.

2. Sebagai pondasi kurikulum Islam. Karena alQur'an menjadi syi'ar agama yang bisa memantapkan akidah dan mengokohkan keyakinan setiap manusia.

3. Sebagai sarana peningkatan akidah siswa. Dengan menanamkan pembelajaran al-Qur'an sejak usia dini maka fitrah suci anak niscaya dapat di lesatarikan atau di kembangkan dengan baik.

4. Sebagai sarana berbuat baik. Di dalam isi kandungan al-Qur'an terdapat pemahaman terkait menamkan kebaikan pada diri manusia dan mampu berbuat baik terhadap sesame manusia.

11Anas Sudjiono, Pengantar Evaluasi Pendidikan, (Jakarta: Rajawali Press, 2003), hlm. 49 
5. BTQ menjadi pelajaran yang ampuh untuk siswa. BTQ sebagai mata pelajaran yang efesien dikarenakan mampu melingkupi dasar dalam membaca serta menulis sehingga dirasa mudah untuk dipelajaridan difahami oleh siswa.

Metode yang diterapkan dalam pembelajaran Baca Tulis al Qur'an (BTQ) ini sama halnya metode pengajaran al Qur'an yang lainnya, akan tetapi yang menjadi pembeda dalam metode Ummi ini dengan metode yang lain hanya pada sistemnya saja. Karena metode Ummi mempunyai 10 sistem berbasi mutu, antaranya adalah:

\section{a. Goodwill Managemen}

Merupakan dukungan pengelolah, pimpinan, kepala sekolah terhadap pembelajaran alQur'an dan penggunakan sistem Ummi disebuah instansi tersebut. Dengan dorongan, antaranya:

1. Mendukung pengembangan pada kurikulum

2. Support terhadap ketersediaan Sumber Daya Manusia

3. Mensupportpada kesejahteraan guru

4. Dukungan dari sarana dan prasarana yang menjadi proses Kegiatan Belajar Mengajar

\section{b. Guru bersertifikasi}

Merupakan pembekalan yang diberikan guru untuk diterapkan pada saat BTQ Ummi. Sertifikasi pada guru al-Qur'an yang menjadi standar awal wajib dimiliki semua pengajar al-Qur'an Ummi. Program ini di jadikan upaya pembakuan mutu setiap guru al-Qur'an metode Ummi. Hal ini dilaksanakan dengan berbagai ketentuan antara lain:

1. Di ikuti semua guru atau calon pengajar al Qur'an dengan keterangan lulus tahsin

2. Dilakukan selama 3 hari dalam satu minggunya

3. Di latih trainer Ummi yang sudah diberi tugas Ummi Foundation dengan adanya Surat Keputusan 
Dewi Ismatul Millah, Implementasi Pembelajaran Baca Tulis al-Qur'an

4. Peserta dari sertifikasi siap meneruskan rencana selanjutnya setelah sertifikasi, dengan magang dan juga supervisi

Program dasar ini memberi tahu maka seorang pendidik mempunyai kelayakan untuk diperbolehkan menjadi pengajar BTQ Ummi. Karena dalam hal ini melalui proses terlebih dahulu, seperti adanya tes, tashih, dan juga sertifikasi yang amaterat. Yang mana kualifikasi sendiri yang diharapkan antaranya:

1. Tartil dalam bacaan alQur'an

2. Menguasai bacaan Ghorib dan Tajwid dasar

3. Konvensional membaca al-Qur'an setiap harinya

4. Memegang metodologi yang ada di Ummi

5. Bejiwa dai juga Murobbi

6. Sangat diisiplin waktu

7. Mampu berkomitmen dengan mutu

\section{c. Tahapan yang Baik dan Benar}

Boleh di lihat dari aspek umum proses dalam belajar dan mengajar sangat butuh dengan adanya prosedur, proses yang bisa di sesuaikan melalui masing-masing karakter di setiap mata pelajaran untuk mencapai tujuan dalam hal tersebut bisa tercapai secara maksimal. Mengajar anak Sekolah Dasar tingkah laku jelas beda dengan anak menengah pertama (SMP), yang menjadi pemecah yang cocok dengan masalah kemampuan diri di dalam kualitas bacaan alQur'an. ${ }^{12}$ Tahapan dalam suatu pembelajaran al-Qur'an yang diterapkan di Madrasah Tsanawiyah Negeri 1 Jombang yang mana antara lain :

\section{Pembukaan}

merupakan suatu pengkondisian pada anak didik mampu dalam mempelajari, di lanjutkan pembuka dengan ucapan salam, menanyakan kabar siswa, dan membaca doa pembuka dalam belajar alQur'an dengan bersama-sama secara baik dan benar.

12Ummi Foundation, Modul Sertifikasi ... hlm.5-6 


\section{Apersepsi}

Pengulang pada materi yang sudah pernah disampaikan untuk bisa di kaitkan pada materi yang hendak di sampaikan.

\section{Penanaman Konsep}

Adalah proses memberi penjelasan terkait materi hendak di sampaikan.

\section{Pemahaman Konsep}

Yakni pemahaman pada siswa tentang persepsi yang telah di ajarkan secara melatih siswa untuk mengkaji sebuah contoh yang sudah tertulis di bawah asal mula bahasan.

\section{Latihan maupun Keterampilan}

Adalah guna melatih hafalan siswa dengan cara mengulang ulang contoh maupun juga berlatih pada halaman latihan pokok dari bahasan.

\section{Evaluasi}

Adalah mengkontrol dan juga membandingkan dengan buku pegangan prestasi siswa terhadap kemahiran dan juga kualitas dalam bacaan siswa dengan individu.

\section{Penutup}

Adalah mengkondisikan siswa konsisten disiplin lalu dilanjut dengan membaca penutup do'a serta di akhiri penutup salam dari Ustad maupunUstadah. ${ }^{13}$

\section{a. Tata Cara Pengajaran alQuran Metode Ummi}

1. Guru dengan kondisi bersila mengatakan salam kepada seluruh peserta didik yang sudah cermat

2. Membaca surah alFatihah bersama-sama dimulai dari taawudz

13Ummi Foundation, Modul Sertifikasi ..., hlm. 10 
3. Dilanjut dengan do'a orang tua juga do'anya Nabi Musa As

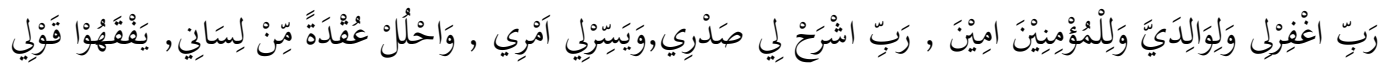

4. Dilanjut dengan bacaan do'a belajar secara terputus - putus jugaditirukan oleh siswa

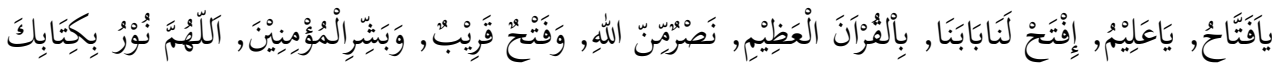

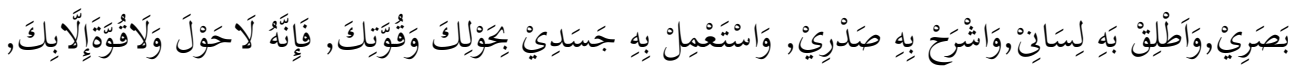

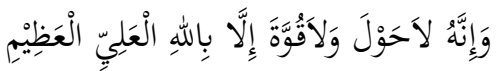

5. Dilanjut dengan menghafalan surah - surah pendek yang menjadi target siswa

6. Meneruskan ulang pelajaran yang sudah dipelajari sebelumnya dengan alat peraga

7. Pemahaman konsep secara bagus dan akurat

8. Pemahaman konsep atau berlatih menggunakan buku jilid

9. Menerapkan keterampilan

10. Memberi tugas di kerjakan rumah sesuai pada kebutuhan

11. Penutup dengan berdo'a di akhir pembelajaran

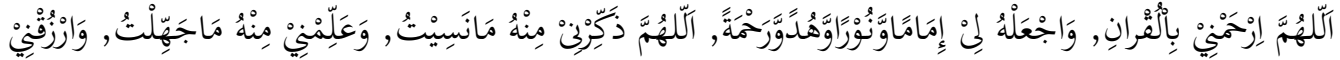

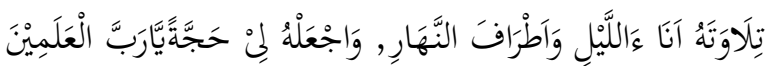

12. Salam

\section{b. Target Sangat Jelas dan Sesuai}

Semua telahdi tetapkan bahan juga ambisi hendak kian gampang memperhitungkan kesampaian indikator berjayanya.Intenspengkajian Qur'an gaya Ummi menduga mengkonsisten objek penunjang yang ingin di iringi bagi segenap institusi konsumen kaidah Ummi, dikarenakananggapan bermula keberhasilan sasaran yang terkandung bisa di amati apakah institut yang mempergunakan metode Ummi bisa prinsip asas yang pernah di tetapkan untuk Ummi Foundation. 
Pengukuhan targer amat fenomenal perlu berbuat evaluiasi terhadap siswa bersama guna kemudian menjalani lalu mengelaborasi treatmen aksi melantas perolehan telaah pada penilaian termaktub.Intensi standar yang didefinitifkan untuk Ummi Foundation adalah sebagai berikut:

TARGET PROGRAM PENGAJARAN AL-QUR'AN SMP/SMU/DEWASA

\begin{tabular}{|c|c|c|c|c|c|c|c|}
\hline Thn & Smt & Tgk & Program & Hal/Juz & Peragam & Tm & $\begin{array}{c}\text { Materi } \\
\text { Hafalan }\end{array}$ \\
\hline \multirow[t]{3}{*}{ VII } & 1 & 1 & Jilid 1 & $1-40$ & Jilid 1 & 15 & $\begin{array}{l}\text { An-Naas, al } \\
\text { Falaq, al } \\
\text { Ikhlash, al } \\
\text { Lahab, an } \\
\text { Nash, al } \\
\text { Kafirun, al } \\
\text { Kausar, al } \\
\text { Maa'un, } \\
\text { Quraisy. }\end{array}$ \\
\hline & & 2 & Jilid 2 & $1-40$ & Jilid 2 & 15 & $\begin{array}{l}\text { Al Fiil, al - } \\
\text { Humazah, al } \\
\text { 'Ashr, at } \\
\text { Takasur, al } \\
\text { Qoriah, al } \\
\text { 'Adiyaat, al } \\
\text { Zalzala }\end{array}$ \\
\hline & 2 & 3 & Jilid 3 & $1-40$ & Jilid 3 & 15 & $\begin{array}{l}\text { Al Bayyinah, } \\
\text { al Qodar, al - } \\
\text { 'Alaq, at Tin, } \\
\text { al Insyirah, } \\
\text { adh Dhuha }\end{array}$ \\
\hline
\end{tabular}




\begin{tabular}{|c|c|c|c|c|c|c|c|}
\hline & & 4 & $\begin{array}{l}\text { Al- } \\
\text { Qur'an }\end{array}$ & Juz 1-5 & $\begin{array}{l}\text { Al- } \\
\text { Qur'an }\end{array}$ & 15 & $\begin{array}{l}\text { Al Lail, } \\
\text { asySyam, al } \\
\text { Balad, al Fajr }\end{array}$ \\
\hline \multirow[t]{2}{*}{ VIII } & 1 & 5 & $\begin{array}{l}\text { Gharib } \\
1-28\end{array}$ & Juz 6-15 & $\begin{array}{l}\text { Ghorib } \\
1-21\end{array}$ & 15 & $\begin{array}{l}\text { Al } \\
\text { Ghosyiyah, al } \\
\text { A'laa, at } \\
\text { Thariq, al } \\
\text { Buruuj, al } \\
\text { Insyiqaq }\end{array}$ \\
\hline & 2 & 6 & $\begin{array}{l}\text { Tajwid } \\
1-20\end{array}$ & $\begin{array}{l}\text { Juz 16- } \\
30\end{array}$ & Tajwid & 15 & $\begin{array}{l}\text { Al } \\
\text { Muthaffifin, } \\
\text { al Infithar, at- } \\
\text { Takwir, } \\
\text { Abasa, an } \\
\text { Naziat, an } \\
\text { Naba' }\end{array}$ \\
\hline \multirow[t]{2}{*}{ IX } & 1 & 7 & $\begin{array}{l}\text { Tahfidh } \\
-1\end{array}$ & Juz 1-5 & & 15 & $\begin{array}{l}\text { Al Mursalaat, } \\
\text { Al Insaan, Al } \\
\text { Qiyyamah, al } \\
\text { Mudastsir, al } \\
\text { Muzammil, } \\
\text { aj- Jin }\end{array}$ \\
\hline & 2 & 8 & $\begin{array}{l}\text { Tahfidh } \\
-2\end{array}$ & $\begin{array}{l}\text { Juz } 16 \text { - } \\
30\end{array}$ & & 15 & $\begin{array}{l}\text { Nuuh, al- } \\
\text { maarij, al- } \\
\text { Haqqah, al- } \\
\text { Qolam, Mulk }\end{array}$ \\
\hline
\end{tabular}

\section{c. Mastery Learning yang Konsisten}

Sebanding pada karakter masing-masing pembimbing al Qur'an metode Ummi sangat memiliki keterikatan terhadap mutu, hingga segenap pengajar al.Qur'an metode Ummi harus memelihara kestabilan sempurnanya mencari ilmu, di karenakan ketuntaan belajar pelajaran lebih dulu akan mempengaruhi keefektifan belajar materi objek selanjutnya. 
Prinsip dalam masteri learning merupakan peseta didik hanya diperbolehkan meneruskan ke dalam jilid selanjutnya jikalau tingkatan jilid sebelumnya mampu di fahamidengan baik dan lancar. Seperti halnya tarjet tiap jilidnya, sebagai berikut:

\begin{tabular}{|c|c|c|}
\hline JILID & SPESIFIKASI & KOMPETENSI \\
\hline 1 & $\begin{array}{l}\text { a. Memperkenalkanse } \\
\text { mua huruf hijaiyah } \\
\text { dari أ-1 } \\
\text { b. Memberi } \\
\text { peengenalan } \\
\text { berharokato } \\
\text { c. Mampu membaca } \\
\text { kalimat yang ber- } \\
\text { kharokat }\end{array}$ & 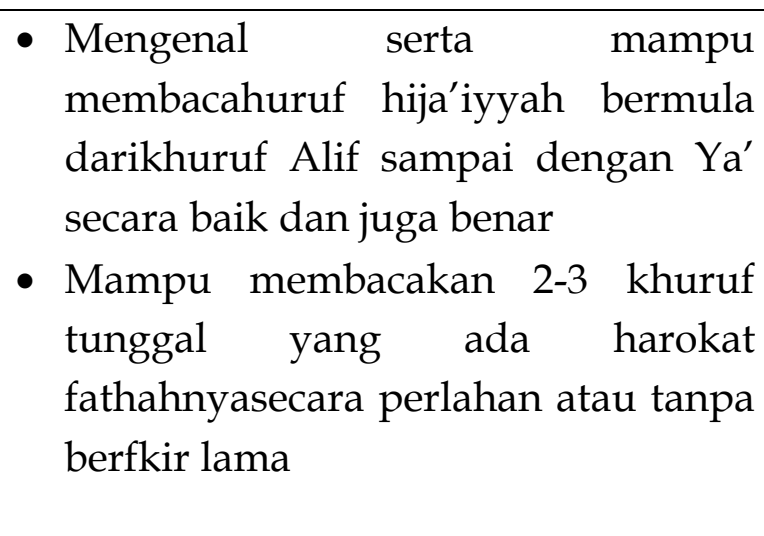 \\
\hline 2 & $\begin{array}{l}\text { a. Mengenalkan tanda } \\
\text { baca (harakat) selain } \\
\text { fathah, kasrah, } \\
\text { dhommah, fathatain, } \\
\text { kasratain, } \\
\text { dhommatain } \\
\text { b. Pengenalan huruf } \\
\text { yang tersambung } \\
\text { dari Alif sampai Ya' } \\
\text { c. Mengenal angka } \\
\text { Arab di mulai 1-99 }\end{array}$ & $\begin{array}{l}\text { - Memahami cara baca Ummi secara } \\
\text { perlahan dan jelas } \\
\text { - Mampu membedakan kharokat } \\
\text { - Bisa menulisnomorArab }\end{array}$ \\
\hline 3 & $\begin{array}{l}\text { a. Apresiasi pada } \\
\text { bacaan Mad Tobi'i di } \\
\text { ucapkan dengan } \\
\text { panjang 1 ayunan } \\
\text { b. Memahami bacaan } \\
\text { Mad Wajiib } \\
\text { Muttashil dan juga } \\
\text { Mad Jaa'iz Munfashil } \\
\text { c. Mengenal angka arab } \\
\text { dari 100-900 }\end{array}$ & $\begin{array}{l}\text { - } \text { Berkecukupan waktu membaca } \\
\text { bacaan panjang/ Mad Thobi'i dibaca } \\
\text { panjang } 1 \text { buaianbersama ukuran } \\
\text { panjang mad yang sahih } \\
\text { - Menguasai bacaan Mad Wajib } \\
\text { Muttashil dan juga Mad Jaiz } \\
\text { Munfasshil di baca panjangn } \\
\text { duadayungan, atau yang dinamakan } \\
\text { dengan coret panjang } \\
\text { - Mampu faham juga bisa menyebut } \\
\text { angka Arab }\end{array}$ \\
\hline
\end{tabular}




\begin{tabular}{|c|c|c|}
\hline 4 & $\begin{array}{l}\text { a. Pengenalan semua } \\
\text { huruf } \\
\text { berkharokatsukun/m } \\
\text { atiserta huruf yang di } \\
\text { tasydid di tekan cara } \\
\text { membacannya } \\
\text { b. Pengenalan huruf- } \\
\text { huruf Fawatir } \\
\text { khusuwar yang } \\
\text { terdapat di jilid } \\
\text { halaman } 40 \quad\end{array}$ & $\begin{array}{l}\text { - Bisa membacakan secara tartil serta } \\
\text { meniti beratkan di setiap huruf yang } \\
\text { di sukun dan juga ditasydid maka } \\
\text { cara membacannya dengan di tekan, } \\
\text { tidak boleh kentor, maupun tawallud } \\
\text { - Mampu memperbedakan huruf yang } \\
\text { menyandang kesamaan perkataan } \\
\text { apabila terdapat huruf di sukun } \\
\text { ataupun di tasydid secara baik dan } \\
\text { benar }\end{array}$ \\
\hline 5 & $\begin{array}{l}\text { a. Pengertiantanda } \\
\text { waqaf } \\
\text { b. pemahaman bacaan } \\
\text { mendengung } \\
\text { c. Pengenalan hokum } \\
\text { lafad Allah (Tafkhim } \\
\text { dan Tarqiq) }\end{array}$ & $\begin{array}{l}\text { - Sanggup dan fasih membaca } \\
\text { latihan/ bagian dari ayat yang } \\
\text { pernah terdapat tanda waqafnya } \\
\text { - Mampu membaca seluruhnya } \\
\text { bacaan yan dibaca Ghunnah } \\
\text { - Mampu membaca dan memarakkan } \\
\text { lafad bertulisan kalimat Allah } \\
\text { "Tafkhim dan juga tarqiq" } \\
\text { - Pandai membaca Fawatir } \\
\text { Khusuwarsecara baik dan benar }\end{array}$ \\
\hline 6 & $\begin{array}{l}\text { a. Identifikasi bacaan } \\
\text { Qolqolah } \\
\text { b. Pengenalan bacaan } \\
\text { yang tidak dengung } \\
\text { c. PemahamanNun Iwad } \\
\text { (Nun kecil) terletak } \\
\text { diawal ayat maupun } \\
\text { di akhir ayat } \\
\text { d. Introduksi bacaan } \\
\text { Ana (tulisannya } \\
\text { panjang namun di } \\
\text { baca pendek) }\end{array}$ & 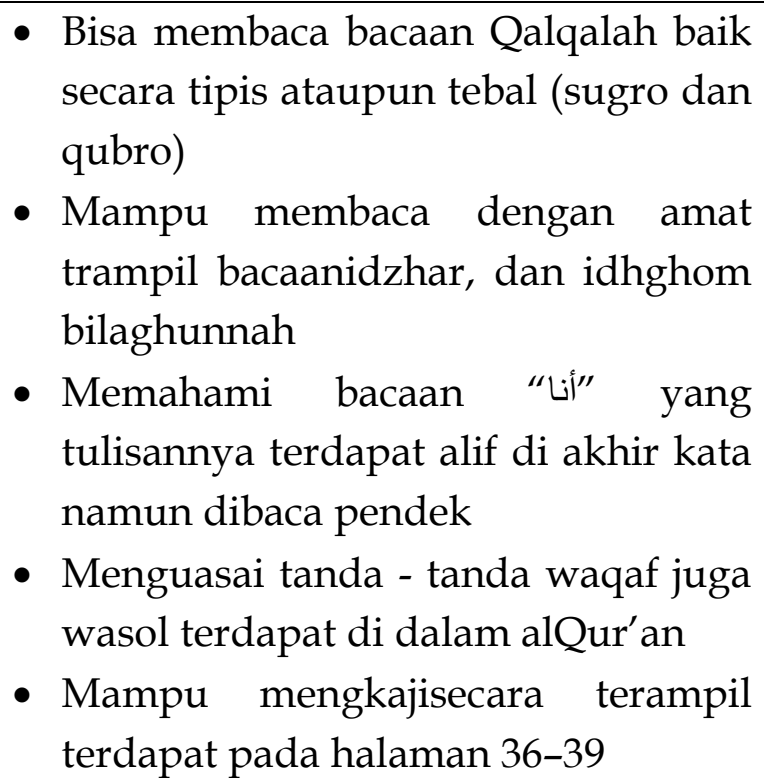 \\
\hline $\begin{array}{c}\text { Tadarus al- } \\
\text { Qur'an }\end{array}$ & $\begin{array}{l}\text { a. Pengenalan } \\
\text { bacaan } \\
\text { al.Qur'an } \\
\text { b. Pengenalan }\end{array}$ & $\begin{array}{l}\text { - } \text { Berupaya menandai al.Qur'an } \\
\text { dengan paduan buku waqof juga } \\
\text { Ibtida' } \\
\text { - Pandai membaca al.Quran secara }\end{array}$ \\
\hline
\end{tabular}




\begin{tabular}{|c|c|c|}
\hline & $\begin{array}{l}\text { memberi } \quad \text { tanda } \\
\text { waqaf maupun } \\
\text { ibtida' pada alQur'an }\end{array}$ & tartiltidak terputus dalam bacaannya \\
\hline $\begin{array}{c}\text { Ghoroib al } \\
\text { Qur'an }\end{array}$ & $\begin{array}{l}\text { a. Pengenalan bacaan } \\
\text { yang perlu berhati- } \\
\text { hatimembacannya } \\
\text { b. Pengenalan bacaan } \\
\text { ghorib ataupun } \\
\text { muskilat }\end{array}$ & $\begin{array}{l}\text { - Mampu dalam bacaan ghorib dan } \\
\text { jugamusykilat dalam al-Qur'an } \\
\text { secara tartil } \\
\text { - Mampu menghafal keseluruhanyang } \\
\text { ada di buku ghorib }\end{array}$ \\
\hline $\begin{array}{l}\text { Tajwid } \\
\text { Pemula }\end{array}$ & $\begin{array}{l}\text { a. Pengenalan dalam } \\
\text { teori ilmu tajwid } \\
\text { dasar keseluruhan }\end{array}$ & $\begin{array}{l}\text { - Memahami dan menghafal materi } \\
\text { tajwid bermula hukum nun } \\
\text { matimaupun tanwin sampai pada } \\
\text { hukum mad, serta mampu } \\
\text { menyebutkan contohnya } \\
\text { - Bisa faham secara merinci }\end{array}$ \\
\hline
\end{tabular}

\section{f. Waktu Memadai}

Proses BTQ ini sangat di butuhkan waktu cukup, karena belajar alQur'an sangat butuh guru yg amat terampil guna mendapatkan skill ketika memprediksi alQur'an dengan baik dan benar (tartil). Seringnya diulang dan di bimbing dalam bacaannya maka makin bisa terampil penguasaan al-Qur'an. ${ }^{14}$ Sebagai mana pembagian waktu dalam proses pembelajaran di bawah ini:

- 5’ Pembukaan (salam, tanya kabar, do'a, pembuka, dan lain lain)

- 30' Menghafalkan surath - surah pendek (Juz 'Ama) sebanding dengan tarjet

- $10^{\prime}$ Pengulangan ( menggunakan alat peraga)

- 30' Latihan individu, baca saling simak, atau baca simak individu

- 5' Penutup (dril, juga do'a penutup)

\section{g. Quality Control Setiap Peserta Didik}

Untuk bisa melindungi juga melindungi kualitas di butuhkan adanya Quality Control ( kontrol kualitas ) atas jalan ataupun dampak

14Ummi Foundation, Modul Sertifikasi .....,hlm.11 
pada produk yangakan di capai. Begitupun saat menjaga serta mempertahankan kualitas pemahaman al.Qur'an di butuhkan quality control secara terus menerus. Di dalam pembelajaran al.Qur'an metode Ummi ada dua macam quality control yakni internal control dan eksternal control.

\section{Quality Control Internal}

Di lakukan secara kordinator pembelajaran al-Quran di Madrasah. Prinsip aktualisasi atas bagian hanya terdapat satu atau sebanyak-banyaknya 2 orang disatu Madrasah yang berkuasa untuk menganjurkan peningkatan pada jilid seseorang peserta didik. Peristiwa ini di lakukan bagaikan cara standarisasi pada pembelajaran al- Qur'an metode Ummi di Madrasah.

\section{Quality Control Eksternal}

Namun bisa di lakukan bagi team Ummi Foundation sendiri juga dari sebagian orang yang sudah di rekomendasikan Ummi Foundation untuk memeriksa secara langsung hasil pembelajaran al.Qur'an metode Ummi di Madrasah. Peninjauan kualitas Eksternalyang mana dikenal sebagai program Munaqosyah.

\section{h. Rasio Guru dan Peserta Didik secara Proposional}

Pencapaian destinasi pembelajaran sangatberkualitas dapat di pengaruhi oleh faktor-faktor korespondensi secara efektif, tatkala itu hubungan interaksi yang efesien sendirimerasadi pengaruhi oleh kesetaraan guru juga seluruh siswa.

Di sebuah pembelajaran al.Quran metode Ummi sendiri sangatlah di perlukan lantaran pembelajaran membaca dan menulis al-Qur'an merupakan anggota dari pembelajaran bahasa beserta kemenangan sangatlah di pengaruhi oleh intensitas interaksi seluruh peserta didik dan guru, disamping belajar bahasa amat memerlukan bimbingan yang memadai untuk mewujudkan skill. Hal ini tidak bisa kesampaian jiklau kesetaraan jumlah pengajar semua siswa tidak proposional. 
Kesetimpalan dari jumlah guru semua peserta didik proposional sendiri berdasarkan standar yang di terapkan dalam penataran membaca jugamenulis al Qur'an (BTQ) dengan menggunakan metode Ummi terdiri 1:10-15 (satu banding sepuluh sampai lima belas) berarti 1 guru paling banyakmemegang 10 (sepuluh) atau 15 (lima belas) peserta didik, gak boleh melebihi dari itu. Jika ada yang lebih dari maksimal jumlah siswa dala setiap kelompoknya maka akan terjadi hambatan dalam pembelajaran dan kesulitan juga terhadap guru dalam melakukan proses aplikasi metode Ummi dalam penelaahan Baca Tulis al-Qur'an.

\section{i. ProgressReportPeserta Didik}

Progress report di perlukan secara informasi jalan menuju hasil belajar siswa. Hal ini terbagi menjadi berbagai jenis selaras bersama kebutuhan sendiri-sendiri. Justru Progress report ini biasa di pergunakan bagaikan alat korespondensi juga penilaian perolehan peserta didi dalam membiasakan diri.

\section{Progress reportpengajar untuk koordintor pembelajaran al.Quran}

Untuk melihat absensi peserta didik, mengkontrol aktivitas mengajar guru, juga kemajuan kapasitas peserta didik dari halaman menuju berikutknya.

\section{Progres report melalui guru menuju ke orang tua}

Hendak melihat dampak anak didik dalam belajar dan kelanjutan kapasitas peserta didik dari halaman semula ke-halaman selanjutnya dan semula jilid awal bisa naik ke-jilid berikutnya.

\section{Progres report dari kordinator pengkajian al Quran bagi kepala} madrasah,

Hendak memahami pertumbuhan dari perolehan selama berlangsungnya pembelajaran peserta didik sebagai klasikal meskipun secara individual, sistem ini juga mampu mendapatkan kemanfaatan bagaikan informasi dari pertumbuhan sebagai kesanggupan untuk membimbing semua pengajar anak didik terhadap kepala sekolah. 


\section{Laporan Progress dari kordinator terhadap pengurus Ummi daerah /} Ummi Foundationi,

Melihat hasil perkembangan jumlah pengkajian untuk mengkontrol layanan diseminasi sumber buku juga alat peraga.

Dari hasil laporan perkembangan tersebut jauh lebih mudah jikalau dilakukan sebuah tindakan juga pengutipan kesimpulan strategis jika sampai terdapat suatu masalah.

\section{j. Koordinator yang Handal}

Pengalaman dari lembaga pendidikan membuktikan bahwasanya pemimpin alqur'an sangat memastikan kejayaan pembelajaran al.Quran di Madrasah. Pengkajian alQuran yang mana hasilnya hampir fasih dapat di pastikan koordinatornyapun fasih juga sebaliknya. Banyaknya problem dalam mutu pembelajaran al Qur'an bersumber masalah di karenakan kurang berfungsinya pemimpin. sehingga koordinator yang handal merupakan satu pilat kunci yang mempengaruhi optimalisasi fungsi pilar-pilar mutu. ${ }^{15}$

Prosedur pembelajaran Baca Tulis al-Qur'an (BTQ) sendiri di Madrasah Tsanawiyah Negeri 1 Jombang ini yang mana sudah sesuai dengan standarisasi metode Ummi yang terdapat dalam sistem metode Ummi di bagian tarjet jelas dan terukur sesuai halaman diatas. Proses dalam pembelajaran ini sangatlah mudah dan menyenangkan, sehingga peserta didik mudah untuk mencapai standarisasi dalam suatu proses pengkajian BTQ menggunakan teknik Ummi terkecuali anak didik mampu mengucapkan, memahami al.Qur'an secara baik juga benar, siswa sanggup hafal juz 'Amma, teori tajwid, ghorib dan juga dalam praktiknya.

Di MTsN 1 Jombang sendiri mempunyai satu koordinator yang kurang handal menurut peneliti, karena pada dasarnya koordinator yang seharusnya mengontrol setiap pembelajaran berlangsung, melakukan evaluasi setelah tuntasnya jilid dan menentukan mampu atau tidaknya siswa tersebut naik jilid atau justru mengulang kembali, akan tetapi Koordinator yang terdapat di

15Ummi Foundation, Modul Sertifikasi ....,hlm.7-9 
lingkup MTsN 1 Jombang kurangnya maksimal dalam penentuan waktu untuk melakukan evaluasi dalam kenaikan setiap jilidnya.

Pembelajaran sudah direncanakan untuk bisa mendukung suatu prosedur dalam mengajar terhadap anak didik, perhitungan suatu yang berlebihanakan suatu peristiwa dalam mencampuri urusan secara langsung oleh peserta didik. ${ }^{16}$ Maka dapat disimpulkan bahwa dalam suatu pembelajaran merupakan suatu aktivitas atau proses yang mampu mengarahkan peserta didik untuk melakukan suatu proses belajar dengan melibatkan unsur manusiawi, dan juga sebagainya.

Dalam suatu pembelajaran terdapat suatu perencanaan dengan menyusun langkah-langkah untuk menyelsaika suatu masalah, dan juga perancangan meliputi sebuah deretan aktivitas demi memastikan destinasi dalam lembaga pendidikan. Setelah tujuan di tetapkan perencanaan yang bersatuan bersama pembentukan rangkaian pola suatu aktivitashendak di lakukan demi mendapatkanarahan tersebut.

Selain itu, dapat kita ketahui bahwasannya metode Ummi sebagai pembelajaran bidang BTQ sudah berkembang pesat di Indonesia saat ini. Sebagai mana teknik ini terbentuk dari teknik-teknik yang lainnya, yang telah sukses mengantarkan seluruh siswa untuk lebih mudah untuk mempelajari alQur'an sehingga mampu menjadikan siswa memahami dan mencatat al-Qur'an dengan Fasih.

Dalam pelaksanaan pengkajian sendiri sesuai pada standarisasi yang ada dalam metode Ummi, dengan adanya target yang diinginkan maka juga adanya penentuan dalam suatu pelaksanaan kajian BTQ. Ketika pembelajaran sendiri pengajar wajib menggunakan alat peraga saat penambahan materi, dan memakai buku jilid saat memahamkan materi.

Dalam sebuah pelaksanaan pembelajaran BTQ Ummi adanya suatu dorongan juga hambatan dalam suatu proses berjalannya pembelajaran BTQ

\footnotetext{
${ }^{16}$ W.S. Winkel., Psiklogi Pengajaran, Sebagaimana di kutip oleh Eveline Sirega dan Hartini Nara, Teori Belajar juga Pembelajaran, (Bogor: Galia Indonesia, 2011), hlm. 12
} 
Dewi Ismatul Millah, Implementasi Pembelajaran Baca Tulis al-Qur'an

Ummi di MTsN 1 Jombang ini, seperti halnya faktor Intern yang berupa jasmaniyah dan psikologis, faktor Ekstern berupa faktor dari keluarga, lingkup sekolah, dan lingkup masyarakat. ${ }^{17}$ Sedangkan yang menjadikannya sebagai dorongan dan hambatan dalam suatupembelajaran BTQ di Madrasah Tsanawiyah Negeri 1 Jombang, yang mana mampu mendorong, mendukung, dan mengajak ikut serta dalam suatu kegiatan pembelajaran tersebut, antaranya adanya guru, adanya siswa, sarana, alat, media, dan juga lingkungan. ${ }^{18}$ metode yang bermutu, adanya dukungan dari lembaga dan orang tua, fasilitas yang memadai, seperti halnya alat peraga, papan, spidol, buku jilid, buku prestasi, dan juga sebagainya. Akan tetapi yang menjadi sebuah hambatan dalam suatu pembelajaran BTQ di MTsN 1 Jombang ini terkait sama minimnya guru bersertifikasi ummi, kualitas guru bermacammacam,kemampuan siswa bervariasi, dan juga tempat untuk belajar yang sangat terbatas.

Untuk solusi dari adanya sebuah hambatan yang menjadikannya pembelajaran BTQ di MTsN 1 Jombang kurang maksimal, maka untuk pembelajaran yang akan datang guru bersertifikat Ummi lebih diperbanyak lagi, sehingga tidak ada lagi hambatan taerkait kurangnya guru yang bersertifikat Ummi terkait metode Ummi yang di terapkan dalam suatu pembelajaran Baca Tulis al Quran (BTQ) di MTsN 1 Jombang, untuk dijadikan solusi dari kwalitas guru yang amat bervariasi atau bermacam-macam maka terjadinya pelaksanaan kordinasi mingguan untuk mengagendakan micro teaching setiap guru secara berurutan, melakukan evaluasi secarabersama untuk menemukan solusi secara bersamaan pula, dan penguatan dalam bacaan alQur'an melalui tadarus bersama dengan cara bergantian, sedangkan solusi untuk kemampuan bervariasi terhadap masing-masing siswa yaitu dengan diadakannya Pre-Test dan membentuk pengelompokan ulang pada siswa.

\section{Kesimpulan}

17Slameto, Belajar dari Faktor-Faktor yang Mempengaruhinya, (Jakarta: Rineka Citra, 2010), hlm. 5471

18Wina Sanjaya, Setrategi Pembelajaran, (Jakarta: Kencana Prenada Media Group, 2016), hlm. 52 
Hasil berdasarkan penelitian terkait dengan implementasimetode Ummi terhadap pembelajaran Baca Tulis al-qur'an (BTQ) di MTsN 1 Jombang, maka dapat diambil kesimpulan bahwasannya metode Ummi ini sangat dianggap lebih mudah untuk diterapkan di lembaga formal maupun non-formal, karena dilihat dari proses yang dipakai selama menerapkan metode ummi yakni bahasanya seorang Ibu, yang mana dalam penyampaian suatu materi dengan langsung, di ulang-ulang, dan tidak lupa dengan didikan kasih sayang amat tulus diberikan seorang Ibu, menjadikanyapembeda antara metode ummi dengan yang lainnya hanya terdapat pada sistem saja. Sistem dalam metode Ummi sendiri ada 10, antara lain : 1) Goodwill Managemen, 2) Guru bersertifikasi, 3) Susunan yang Baik dan juga Benar, 4) Tarjet Jelas dan Terukur, 5) Masteripemelajaranamat Konsisten, 6) kesempatan yangcukup, 7) Pengawasan Qualitiamat Intensif, 8) Rasio pengajar dan pelajar yang Proposional, 9) Laporan kemajuanSetiap pelajar, 10) Kordinator yang Ahli.

Banyak sekali tujuan dan manfaat pembelajaran di dalam Baca Tulis alQuran (BTQ), yang mana semua berkaitan dengan kehidupan manusiadalam keadaan sehari-harinya. Tujuan dalam hal ini Baca Tulis al-Qur'an (BTQ) antara lain, mempertimbangkan caramemahami alQur'an secara baik juga benar, menulis, mampu faham, serta mengetahui isi terdapat di dalam al-Quran. Manfaat pembelajaran dalam baca tulis ini diantaranya, sebagai obat, peringatan, pelindung, pengajaran, dan alat komunikasi dengan sang penciptaNya (Allah). Dan juga terdapat alasan pentingnya adanya pembelajaran BTQ ini sebagai kewajiban untuk semua umat muslim, mampu menjaga dari keaslian ayat al.Qur'an sehinga tidak terjadi perubahan lafadz dan maknannya, sebagai motivasi, modal utama, mukjizat, dan menjadi pegangan serta pondasi manusia dalam keadaan sehari-harinya.

Faktor pendukung dalam penerapan metode ini antaranya guru dan siswa, dukungan dari lembaga dan orang tua, fasilitas yang memadai, dan adanya dan koordinator yang handal, sedangkan yang menjadikannya sebagai faktor penghambat dalam suatu penerapan metode ummi ini adalah 
Dewi Ismatul Millah, Implementasi Pembelajaran Baca Tulis al-Qur'an

terbatasnya guru al-Qur'an Ummi berstatus sudah bersertifikasi, terbatasnya tempat sehingga menjadikannya kurang efektif proses penggunaan metode dalam belajar Baca Tulis alQur'an (BTQ) di MTsN 1 Jombang. Akan tetapi setelah adanya penghambat dalam suatu proses pembelajaran tersebut, maka terdapatlah pula solusi yang akan bisa memecahkan masalah dari hambatan tersebut, yang mana di tahun ajaran berikutnya guru atau pengajar al-Qur'an yang bersertifikat Ummi akan di tambah lebih banyak dan tempat yang dianggap minimalis akan diperluas, sehingga menjadi maksimalnya proses pembelajaran.

\section{DAFTAR PUSTAKA}

Foundation, Ummi, Modul sertifikasi Metode Ummi, Surabaya: Ummi Foundation, 2012

Ghony, M. Djumaidi \& Fauuzan al Mansur, Metodologi Pnelitian Kualitatif, Yogyakarta: ArRuuz Media, 2012

Hosna, Rofiatul dan Samsul, Menjlitkan Pembelajaran dengan Prinsip Belajar. Malang: Intlegensia Media, 2015

Kurniya, Agus, Implementasi Metode AlHidayah di dalam Pembelajaran Baca Tulis alQur'an, Jurnal Tasqif, Jurnal Pemikiran dan Peneltian Pendidikan, Vol. 15, No. 1, 2017

Kusuma, Yuuanda, “Model Perkembangan Pembelajaran BTQ di TPQ/TPA Indonesia", Jurnal Agama Islam,no. 1, 2018

Mahmud, Metode Penelitian Pendidikan, Bandung: CV Pustaka Setia, 2011

QS. Al-Alaq (96): 1-5

Sanjaya, Wina, Setrategi Pembelajaran, Jakarta: Kencana Prenada Mdia Grup, 2016

Selameto, Belajar dan Faktor yang Mempengaruhi, Jakarta: Rineka Citra, 2010

Sugiono, Metode Penelitian Kuantitatif, Kualitatif, dan RED, Bandung: Alfabet, 2016

Sujiono, Anas, Pengantar Evaluasi Pendidikan, Jakarta: Rajawali Pres, 2003 